\title{
Evaluation of Brinjal (Solanum melongena L.) Genotypes for Flowering and Yield Parameters
}

\author{
Hadassah Chinthagunti", D.A. Sarnaik and Dhananjay Sharma \\ Department of Horticulture, College of Agriculture, Indira Gandhi Krishi Viswavidhyalaya, \\ Raipur - 492 012, Chhatisgarh, India \\ *Corresponding author
}

\begin{abstract}
A B S T R A C T
A comparative study on 16 brinjal genotypes ( 15 hybrids and 1 open pollinated variety) for flowering and yield attributing parameters was conducted at Indira Gandhi Krishi Viswavidhyalaya, Raipur, during rabi 2012-2013. Pusa Hybrid-6 is found to be statistically superior in earliness over the other hybrids in days to 50\% flowering (55.67)

\begin{tabular}{|c|}
\hline Keywords \\
\hline $\begin{array}{l}\text { Brinjal, Evaluation, } \\
\text { Flowering, Yield }\end{array}$ \\
\hline Article Info \\
\hline $\begin{array}{l}\text { Accepted: } \\
\text { 24 November } 2018 \\
\text { Available Online: } \\
\text { 10 December } 2018\end{array}$ \\
\hline
\end{tabular}
and days to first picking (83). Earliness is of economic importance as in case of vegetables, early crop fetch good price. Percent fruit set is highest in 2012/BRRHYB-4 (61.94\%) which is also the highest bearing hybrid in terms of yield per plant $(2.60 \mathrm{~kg})$. The maximum number of flowers and fruits per cluster was observed in 2011/BRRHYB-7 with 5.77 flowers per cluster and 3.53 fruits per cluster, but it had only $61.08 \%$ fruit set as against the maximum of $61.94 \%$ in 2012/BRRHYB-4. Brinjal hybrid 2011/BRRHYB-7 had 52.8 fruits per plant which is the highest number of fruits per plant during the whole fruiting season. Minimum number of fruits per plant (7.20) and subsequently, less yield per plant (1.25 kg) was observed in hybrid 2011/ BRRHYB-3. Maximum yield in 2012/ BRRHYB-7 (472.92 q/ha) was due to higher yield per plant $(2.27 \mathrm{~kg})$ and whereas in 2012/ BRRHYB-4 higher yield per hectare (446.61 q/ha) was attributed to its higher number of fruits per cluster (2.39), percentage fruit set (61.94\%), number of fruits per plant (44.73) and yield per plant $(2.60 \mathrm{~kg})$ even though it showed less individual fruit weight $(88.42 \mathrm{~g})$.
\end{abstract}

\section{Introduction}

Brinjal or egg plant, belongs to family Solanaceae. The plant is erect, semi-erect or prostate, herbaceous and branched in nature. Normal flower of brinjal is pentamerous and hermaphrodite, solitary or in 2-7 flowered cymes. Heterostyly is common feature in multi flowered cymes except in bunchy type cultivars. The cultivated brinjal is presumed to be of Indian origin with China as secondary centre of origin. It has been cultivated for many centuries in India, China, Arabia and was probably introduced into Europe during the Moorish invasion of Spain in $16^{\text {th }}$ century.

In India, brinjal is cultivated in an area of 669 thousand ha with a production of 12,400 thousand tonnes per year (Horticultural Statistics at a Glance, 2017). In view of increasing population, there is a need for increased production and productivity levels 
of brinjal. Further there is high local preferences for colour, shape, taste, there are specific genotypes suited for specific locality. It is not possible to have one common cultivar which may be suitable for different areas and local preferences. It is therefore required to improve the locally preferred cultivars for high yield and adaptation or development of new hybrid combinations.

Hybrid varieties have many advantages over the local varieties. Scientific and accurate breeding programs have made it possible not only to bring out the outstanding qualities of the parent plants, but in most cases these qualities have been enhanced and new desirable characteristics added to the resultant hybrid plants. In addition to qualities like good vigor, trueness to type, heavy yields and high uniformity which hybrid plants enjoy, other characteristics such as earliness, disease resistance and good holding ability have been incorporated into most $\mathrm{F}_{1}$ hybrids. Uniform plant habit and maturity, coupled with uniformity in shape or size have made hybrid vegetables extremely suitable for commercial cultivation. Today we have many hybrid varieties available in the market, and it necessitates their evaluation to find out the best suited varieties for a particular place that fulfill the requirement of farmers and consumers of specific choice. Looking at above facts, an experiment was designed to evaluate the hybrids for flowering and yield parameters.

\section{Materials and Methods}

The present experiment was conducted during the rabi season of 2012-13 at Horticulture Farm, Department of Horticulture, College of Agriculture, Indira Gandhi Krishi Viswavidyalaya, Raipur (C.G.).

Raipur is situated at the $21^{\circ} 16^{\prime} \mathrm{N}$ latitude and $81^{\circ} 36^{\prime}$ E longitude at an altitude of 289.56 meters above mean sea level. Raipur, the place of investigation, is a sub-humid region. It comes under the seventh agro-climatic zone of the country, i.e. eastern plateau and hills. The soil of the experimental site is clay with average fertility and drainage.

The experiment was laid out in a randomized complete block design (RCBD) with three replications comprising 16 genotypes $\left(15 \mathrm{~F}_{1}\right.$ hybrids +1 open pollinated variety). The treatments consisted of hybrids 2011/ BRRHYB-1， 2011/ BRRHYB-2， 2011/ BRRHYB-3， 2011/ BRRHYB-4， 2011/ BRRHYB-5, 2011/ BRRHYB-7, 2012/ BRRHYB-2, 2012/ BRRHYB-3, 2012/ BRRHYB-4, 2012/ BRRHYB-5, 2012/ BRRHYB-6, 2012/ BRRHYB-7, EPH-178, Kashi Sandesh, Pusa Hybrid-6 and an open pollinated variety Swarna Mani Black.

Individual plots were observed for normal plants representing each genotype the following observations were recorded during the crop growth period on ten randomly selected competitive plants, which were tagged in each plot of every replication. Observations were recorded on days to $50 \%$ flowering, days to first picking, number of flowers per cluster, number of fruits per cluster, percentage fruit set, number of fruits per plant, average fruit weight (g), yield per plant $(\mathrm{kg})$ and yield per ha (q/ha). The data was analyzed by adopting the standard procedure of Panse and Sukhatme (1985) and using AGRISTAT software. Wherever, the results were found significant, critical differences (CD) were computed at 5 percent level of probability to draw statistical conclusions.

\section{Results and Discussion}

The results of the present investigation for flowering and yields parameters are depicted in Table 1. Mean performance of treatments for days to fifty percent flowering ranged from 45.00 days (2012/BRRHYB-7) to 71.33 days 
(2011/BRRHYB-4) with an overall mean of 60.92 days. The variation in flowering time in different varieties may also be due to genetic character of the variety and also affected by level of gibberellin in the plants of different varieties. Earliness results in a longer time of production and therefore, a greater total yield as observed in 2012/BRRHYB-7. Entry 2012/BRRHYB-7 showed minimum number of days to fifty percent flowering (45) and recorded maximum yield per hectare (472.92 $q / h a)$. As early crop fetches higher price in the market, earliness has additional advantage over the rest of the harvest. The findings are in consonance with Munoz-Falcon et al., (2006). Days required for $50 \%$ flowering is a specific character of individual treatment. As India is the origin of brinjal, there is a high variability in the treatments as regards flowering. The genotype of the individual may be the probable reason for variation observed for this character (days to $50 \%$ flowering) under the present study.

The minimum number of days to first picking was found in Pusa Hybrid-6 (83.00 days) which was found to be statistically at par with 2012/ BRRHYB-6 (87.6 days). The maximum number of days to first picking (105.367 days) was observed in 2011/BRRHYB-5 (105.367 days) which was found to be to be statistically at par with 2012/ BRRHYB-2 (101.3 days) and 2011/ BRRHYB-3 (99.93 days) and significantly superior over the rest of the treatments. Earliness is of economic importance as in case of vegetables, early crop fetch good price.

All the treatments under the present study have exhibited flowering in clusters except 2012/ BRRHYB-3 which had an average of 1.65 flowers per cluster. The treatments 2011/ BRRHYB-7 and 2012/ BRRHYB-4 displayed fruiting in clusters while all the remaining treatments showed solitary fruiting habit. The maximum number of flowers and fruits per cluster was observed in 2011/BRRHYB-7 with 5.77 flowers per cluster and 3.53 fruits per cluster, but it had only $61.08 \%$ fruit set as against the maximum of $61.94 \%$ in 2012/BRRHYB-4. The minimum number of flowers per cluster was observed in 2012/BRRHYB-3 (1.65) which was found to be statistically similar to Kashi Sandesh (2.1). The variation in number of flowers of cluster (1.65 - 5.67) may be due to genetic characteristics of different genotypes under present investigation. The variation in number of flowers of cluster (1.65 - 5.67) may be due to genetic characteristics of different genotypes under present investigation. Variation in number of flowers per cluster due to different treatments observed in present investigation is in close proximity to the findings of Sharma and Swaroop (2000).

The treatments 2011/ BRRHYB-7 (3.53 fruits per cluster) and 2012/ BRRHYB-4 (2.39 fruits per cluster) displayed fruiting in clusters. Greater number of fruits per cluster was also due to more number of flowers per clusters in these two treatments.

The rest of the treatments are observed to be solitary bearing in habit, bearing only single fruit per cluster. So, the number of fruits per cluster ranged from 1 to 3.53 with an overall average of 1.25 fruits per cluster. The solitary bearing genotypes with an average of 1 fruit per cluster are 2011/ BRRHYB-1, 2011/ BRRHYB-2， 2011/BRRHYB-3， 2011/ BRRHYB-4， 2011/BRRHYB-5，2012/ BRRHYB-2, 2012/ BRRHYB-3, 2012/BRRHYB-5, 2012/BRRHYB-6, 2012/BRRHYB-7, EPH-178, Kashi Sandesh, Pusa Hybrid-6 and Swarna Mani Black.

The findings are in accordance with Paikra (2001) who studied $11 \quad \mathrm{~F}_{1}$ hybrids under Raipur condition and noted that number of fruits per plant ranged from 1.60 to 3.50 . 
Percentage of fruit set ranged from $24.39 \%$ (2011/BRRHYB-1) to $61.94 \%$ (2012/ BRRHYB-4) with an overall average of $39.7 \%$. The maximum percentage of fruit set was observed in 2012/ BRRHYB-4 (61.94\%) which was found to be statistically at par with 2012/ BRRHYB-3 (61.30\%) and 2011/ BRRHYB-7 (61.08\%). Higher fruit set in 2011/ BRRHYB-7 and 2012/ BRRHYB-4 $(61.08,61.94)$ was due to high number of flowers per cluster. Higher percentage of fruit set in 2012/ BRRHYB-3 nevertheless of the fact that it recorded lower number of fruits per cluster was due to its lower number of flowers per cluster.

Hybrid 2011/ BRRHYB-7 had maximum number of fruits per plant (52.8) while, hybrid 2011/ BRRHYB-3 had minimum number of total fruits per plant (7.20). The overall mean was 17.40 fruits per plant. The increased number of fruits per plant in 2011/ BRRHYB7 (52.80) was due to increase in number of flowers per cluster (5.77), number of fruits per cluster (3.53) and percentage fruit set (61.08\%). Similar findings were reported by Mishra (2012).

Total fruit yield per plant ranged from $1.03 \mathrm{~kg}$ (2011/ BRRHYB-7) to $2.60 \mathrm{~kg}$ (2012/ BRRHYB-4). Maximum fruit yield per plant (2.60 kg) recorded in 2012/ BRRHYB-4 was may be due to higher number of fruits per cluster (2.39), percentage fruit set (61.94\%) and number of fruits per plant (44.73) even though it showed less individual fruit weight (88.42 g). The results are in concordance with those of Prabhu et al., (2008) and Dharwad et al., (2009).

Table.1 Performance of brinjal genotypes for flowering and yield parameters

\begin{tabular}{|c|c|c|c|c|c|c|c|c|}
\hline Treatments & $\begin{array}{c}\text { Days to } \\
\mathbf{5 0 \%} \\
\text { flowering }\end{array}$ & $\begin{array}{c}\text { Days to } \\
1^{\text {st }} \\
\text { picking }\end{array}$ & $\begin{array}{c}\text { Number } \\
\text { of } \\
\text { flowers } \\
\text { per } \\
\text { cluster }\end{array}$ & $\begin{array}{c}\text { Number } \\
\text { of fruits } \\
\text { per } \\
\text { cluster }\end{array}$ & $\begin{array}{l}\text { Percent } \\
\text { fruit set }\end{array}$ & $\begin{array}{c}\text { Number } \\
\text { of fruits } \\
\text { per } \\
\text { plant }\end{array}$ & $\begin{array}{l}\text { Yield } \\
\text { per } \\
\text { plant } \\
(\mathrm{kg})\end{array}$ & $\begin{array}{l}\text { Yield } \\
\text { per ha } \\
\text { (q) }\end{array}$ \\
\hline 2011/ BRRHYB-1 & 62.67 & 92.97 & 4.10 & 1.00 & 24.39 & 7.67 & 1.03 & 203.55 \\
\hline 2011/ BRRHYB-2 & 56.67 & 89.47 & 3.42 & 1.00 & 30.14 & 9.33 & 1.38 & 205.14 \\
\hline 2011/ BRRHYB-3 & 65.67 & 99.93 & 3.00 & 1.00 & 36.45 & 7.20 & 1.25 & 167.96 \\
\hline 2011/ BRRHYB-4 & 71.33 & 92.63 & 4.30 & 1.00 & 24.42 & 9.60 & 1.56 & 184.72 \\
\hline 2011/ BRRHYB-5 & 65.00 & 105.37 & 3.50 & 1.00 & 29.83 & 9.60 & 1.38 & 238.01 \\
\hline 2011/ BRRHYB-7 & 62.67 & 91.57 & 5.77 & 3.53 & 61.08 & 52.80 & 1.03 & 130.64 \\
\hline 2012/ BRRHYB-2 & 68.33 & 101.3 & 2.27 & 1.00 & 44.11 & 15.73 & 1.39 & 293.5 \\
\hline 2012/ BRRHYB-3 & 61.67 & 95.57 & 1.65 & 1.00 & 61.30 & 8.60 & 1.67 & 324.44 \\
\hline 2012/ BRRHYB-4 & 59.67 & 89.00 & 3.90 & 2.39 & 61.94 & 44.73 & 2.60 & 446.61 \\
\hline 2012/ BRRHYB-5 & 65.00 & 94.33 & 3.85 & 1.00 & 26.05 & 27.27 & 1.64 & 280.71 \\
\hline 2012/ BRRHYB-6 & 55.00 & 87.60 & 3.50 & 1.00 & 28.63 & 11.07 & 2.50 & 373.52 \\
\hline 2012/ BRRHYB-7 & 45.00 & 94.50 & 2.30 & 1.00 & 43.70 & 11.60 & 2.27 & 472.92 \\
\hline EPH-178 & 65.00 & 90.90 & 3.52 & 1.00 & 28.54 & 32.3 & 2.06 & 418.91 \\
\hline Kashi Sandesh & 62.33 & 92.47 & 2.10 & 1.00 & 48.28 & 11.67 & 1.85 & 379.33 \\
\hline Pusa Hybrid-6 & 55.67 & 83.00 & 2.40 & 1.00 & 41.72 & 8.80 & 1.43 & 220.35 \\
\hline $\begin{array}{l}\text { Swarna Mani } \\
\text { Black }\end{array}$ & 63.00 & 94.47 & 2.27 & 1.00 & 44.64 & 10.47 & 1.89 & 278.26 \\
\hline Mean & 60.92 & 93.44 & 3.24 & 1.25 & 39.70 & 17.40 & 1.68 & 288.66 \\
\hline SEm \pm & 1.96 & 2.62 & 0.31 & 0.11 & 3.97 & 1.73 & 0.17 & 30.67 \\
\hline $\mathbf{C D}$ & 5.66 & 7.58 & 0.89 & 0.31 & 11.46 & 4.99 & 0.49 & 88.58 \\
\hline $\mathrm{CV} \%$ & 5.51 & 4.86 & 16.45 & 15.09 & 17.31 & 17.18 & 17.34 & 18.40 \\
\hline
\end{tabular}


Total yield per hectare ranged from 130.64 quintals (2011/ BRRHYB-7) to 472.92 quintals (2012/ BRRHYB-7) with an overall mean of 288.66 quintals yield per hectare. Yield is a complex character and is determined by many genes and is largely influenced by environmental conditions. The varietal differences always play an important role in the determination of yield. In the present study data regarding yield per plot as well as per hectare showed significant differences among the treatments. The yield being a polygenic trait is a result of component characters like number of fruits per plant and fruit weight. Yield in each treatment is a result of the cumulative effect of different characters. Maximum yield in 2012/ BRRHYB-7 (472.92 q/ha) was due to higher yield per plant $(2.27 \mathrm{~kg})$ and whereas in 2012/ BRRHYB-4 higher yield per hectare $(446.61 \mathrm{q} / \mathrm{ha})$ was attributed to its higher number of fruits per cluster (2.39), percentage fruit set $(61.94 \%)$, number of fruits per plant (44.73) and yield per plant $(2.60 \mathrm{~kg})$ even though it showed less individual fruit weight $\left(88.42\right.$ g). $\quad F_{1}$ hybrid 2011/BRRHYB-7 registered minimum yield per hectare (130.64 $\mathrm{q} / \mathrm{ha}$ ) albeit it gave maximum number of fruits per plant (52.8) which is due to the less weight of fruit $(25.2 \mathrm{~g})$ and yield per plant $(1.03 \mathrm{~kg})$. Similar results were reported by Thangamani and Jhansirani (2012). Taking the above results into consideration, the hybrids 2012/ BRRHYB-7 (472.92 q/ha) and 2012/ BRRHYB-4 (446.61 q/ha) can be suggested for cultivation in the Raipur plains.

\section{References}

Dharwad, N.A., Salimath, P.M. and Patil, S.A. 2009. Association and path coefficient analysis in elite germplasm lines of brinjal (Solanum melongena L.). Karnataka J. of Agri. Sci., 22(5): 965-966.

Horticultural Statistics at a Glance, 2017. Ministry of Agriculture and Farmers Welfare, Government of India

Mishra, Malayaj Narhari, 2012. Studies on variability, correlation and genetic divergence in open pollinated brinjal genotypes (Solanum melongena L.). M.Sc. (Ag.) Thesis, IGKV, Raipur (C.G.).

Munoz-Falcon, J.E., Prohens, J, RodriguezBurruezo, A. and Nuez. F. 2008. Potential of local varieties and their hybrids for improvement of eggplant production in the open field and greenhouse cultivation. J. Food, Agric. and Environment, 6(1): 83-88.

Panse VG, and Sukhtme PV. Statistical Methods for Agricultural Workers. ICAR, New Delhi, 145-155.

Prabhu M., Natrajan, S. and Veeraragavathatham, D. 2008. Correlation and path coefficient analysis in eggplant (Solanum melongena L.). Indian J. of Agri. Res., 42(3):232 - 234.

Sharma, T.V.R.S. and Swaroop, Kishan, 2000. Genetic variability and character association in brinjal (Solanum melongena L.). Indian J. Hort., 57(1):59-65.

\section{How to cite this article:}

Hadassah Chinthagunti, D.A. Sarnaik and Dhananjay Sharma. 2018. Evaluation of Brinjal (Solanum melongena L.) Genotypes for Flowering and Yield Parameters. Int.J.Curr.Microbiol.App.Sci. 7(12): 3101-3105. doi: https://doi.org/10.20546/ijcmas.2018.712.355 